\title{
Animals in Contemporary Spanish Newspapers ${ }^{1}$
}

\author{
John Beusterien
}

For those teaching Spanish in the United States, focusing on language, culture, and themes related to the Iberian Peninsula, it is inevitable and necessary to confront the question of place. Teaching the question of place means that the Spanish instructor teaches students about regional Iberian places. It also means knowing and communicating an awareness of place with respect to the role of Spanish in the United States because, on the Iberian Peninsula as well as in the United States, the meaning of "Spanish" is fraught with historical, regional, and political complexity.

Ecological urgency permeates our contemporary sense of place and the complex meaning of "Spanish," as the editors of this volume remind us. Place is integrally linked to the living beings that are nourished from or destroy it and, more than ever, professors in the humanities and languages are confronting a consideration of space not only linked to the question of human culture, but also a broad spectrum of beings.

My experience of teaching Spanish in the southern portion of the United States' high plains has meant examining and recovering the deep Spanishspeaking history of the area as well as examining its ecology. Because an incredibly rich animal history pervades the area, from horse and cattle ranch culture to the decimation of the bison, I have studied animals as a complementary way to understand space in the context of a focus on the Spanish-speaking history and culture of the region of the Texas Panhandle.

Teaching a local perspective in the United States, however, has not meant ignoring Spain. Providing knowledge of current events surrounding animals in Spain has been a fruitful avenue through which the lines and colors, the grass and the winds, of the space of the southern high plains has taken on definition, meaning, and, ironically, tangible materiality, despite the ocean and land that separates the southwest United States from the Iberian Peninsula.

The consideration of ecology with a special emphasis on animals estranges students in a positive way from their local space. By reading about

\author{
A Polemical Companion to \\ Ethics of Life: Contemporary Iberian Debates \\ Hispanic Issues On Line Debates 7 (2016)
}


the current events surrounding animals from newspapers from Spain, they come to terms at once with a different dialect of Spanish and radically different faunal ecologies. Animals unique to Spain, such as the Iberian lynx, pervade the headlines. For example, in January and February of 2015, El Pais printed articles devoted to the question of how to limit incidences of lynx road kill (Salas; Donaire).

Articles about local animal life also highlight how Iberian wolves, the Iberian imperial eagle, and even introduced animals, like the raccoon, are tracked through hidden cameras (see my essay for the volume, Ethics of Life: Contemporary Iberian Debates). The regional ecological landscapes in Spain have the appearance of the wild, but are nonetheless sites of cultural production mediated by technology. Optical technology is often described as implanted in secret in the animal's space. El Mundo reported in February 2015 that an installed webcam is now recording an endangered pair of black vultures in the depths of the National Park in Guadarrama (Durán and Somolinos). The footage from the webcam-installed next to a nest 30 meters high in a pine tree in the depths of the forest-is designed to watch copulation, incubation, and the growth of the vulture chicks. The El Mundo article is exemplary of a local node of conservation, that is, the preservation of an endangered species from a specific Spanish region under the auspices of the methods employed by a global ecological group, Birdlife International.

The webcam feeds live data and, based on the optical technology, the author of the article concludes that the nest will now make the black vulture part of nuestra familia (our family). Reading about the animal forces the question of how we love the animal as part of a profoundly new ecology and ethics of family that even includes slaughter. Another article from February 2015 focuses on a goose farm run by Eduardo Sousa and conceives this idea of a new family in another way. The article explains that Sousa produces the best foie in the world and provides his secret: the special way he treats the animal and that he has discovered an ecological and ethical way to raise his geese (Mucha).

One of the goals of an edition of essays that consider the ethics of life in contemporary Spain is to force scholars and teachers to reconsider what constitutes the space of their scholarship and their practice, that is, what is our ecological and ethical imperative. Put slightly differently, how do Peninsular scholars come to terms with what responsibility is owed to beings, human and not, or to alter the term from the article about the vultures, who exactly constitutes nuestra familia?

Debates - both academic and practical-about the treatment of animals in Spain and the United States oftentimes interconnect. Cary Wolfe, a leading scholar in animal studies, has commented on the special case of Spain with regards to the treatment of the animal. On a more applied, hands- 
on level, Bob Hancock, a Kentucky native, returned from a tour of a Spanish pig farm and a town matanza (slaughterhouse). After witnessing the age-old Spanish communal animal slaughter method, he started raising pigs himself back in Kentucky.

My article attempts to unite both academic and everyday practice through the study of the animal in contemporary Spanish newspapers. The topic itself, in the context of a course about the region, impels students to consider their space. Although the animals and situations are distinct, comparisons are inevitable, especially when comparing European bison in the Atapuerca region with attempts to reintroduce bison in West Texas.

The introduction of animals in Spain is not an exercise in exoticizing a different space for students. It is one in which they begin to form a conceptualization of their own space, the Llano Estacado, through a unique lens. The overlapping of Spanish faunal ecology in the context of the history of the faunal ecology of the landscape of one's own university can contribute to profound transformations, because it forces a consideration of what role students will play in new landscapes of the near future.

In West Texas, alternative imaginings of place are necessary to provide alternatives to fracking or cotton agriculture. These imaginings include the visualization of grasslands living in synchronicity with animal life as they had for thousands of years. Future ecological practice will depend on human technologies and the ecology of an artificial wild, that is, a recognition of how the emerging biotechnologies of plant, animal, and human life takes shape. This sort of thinking is not reserved for students in the environmental sciences, but those across the curriculum and, yes, even students of Spanish. Rediscovering an ecological sense of place at home through the examination of faunal ecology in Spain creates lasting awareness of a homeland, stimulates a desire to preserve, conserve, and envision, and raises collective consciousness about the ecological crisis.

\section{Notes}

1. I thank Fernando Ruiz for his invaluable research help.

\section{Works Cited}

Donaire, Ginés. "El apunte de linces atropellados acelera un plan urgente de prevención." El País. 15 Feb. 2015. Web. 12 April 2015.

Durán, Luis Fernando and Daniel Somolinos. "Instalada una 'webcam' en el nido de un buitre negro en Guadarama." El Mundo. 25 Feb. 2015: 34. Print.

Mucha, Martín. "Foie ético de oca mimada." El Mundo. 22 Feb. 2015: 18-19. Print.

HIOL Debates $•$ Hispanic Issues On Line 
Salas, Javier. "Una concentración motera amenaza a un lince en un entorno protegido." El País. 27 Jan. 2015. Web. 23 April 2015.

Wolfe, Cary. "Human, All Too Human: 'Animal Studies' and the Humanities." PMLA: Publications of the Modern Language Association of America 124 (2009): 564-575. Print.

Beusterien, John. "Animals in Contemporary Spanish Newspapers." A Polemical Companion to Ethics of Life: Contemporary Iberian Debates. Ed. Katarzyna Beilin and William Viestenz. Hispanic Issues On Line Debates 7 (2016): 11-14. Web. 